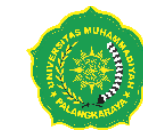

UMP

SULUH

JURNAL BIMBINGAN DAN KONSELING

http: //journal.umpalangkaraya.ac.id/index.php/suluh Volume 4 Nomor 2, Februari 2019 (1-3)

\title{
KONSELING KELOIMPOK DENGAN TEKNIK SOSIODRAMA UNTUK MENINGKATKAN KEMAMPUAN INTERAKSI SOSIAL PADA PESERTA DIDK MTS HIDAYATUL INSAN PALANGKA RAYA
}

\section{Group Counseling With Sosiodrama Techniques To Improve The Ability Of Social Interactions In Participants In MTs Hidayatul Insan Palangka Raya}

\author{
'Diplan ${ }^{2}$ Yuni Budiyaningsih
}

'Universitas Muhammadiyah palangkaraya, Palangka Raya, Kalimantan Tengah, Indonesia

${ }^{2}$ Universitas Muhammadiyah palangkaraya, Palangka Raya, Kalimantan Tengah, Indonesia

\begin{tabular}{|c|c|}
\hline ARTIKEL INFO & ABSTRAK \\
\hline Diterima & $\begin{array}{l}\text { Tujuan penelitian ini mengetahui kemampuan interaksi sosial yang rendah dapat } \\
\text { ditingkatkan dengan menggunakan layanan Konseling Kelompok dengan Teknik }\end{array}$ \\
\hline Desember 2018 & $\begin{array}{l}\text { Sosiodrama pada peserta didik kelas VII MTs Hidayatul Insan Palangka Raya. Populasi } \\
\text { dalam penelitian ini adalah } 66 \text { peserta didik. Jumlah sampel Penelitian terdiri dari } 7 \\
\text { peserta didik. Penelitian ini termasuk penelitian kuantitatif, metode penelitian adalah } \\
\text { metode pre eksperimen One-group pre-test dan post-test design.. Teknik } \\
\text { pengumpulan data menggunakan skala interaksi sosial. Teknik analisis data yang } \\
\text { digunakan adalah uji t (paired sample T test) yang tergolong dalam statistik } \\
\text { parametrik. }\end{array}$ \\
\hline $\begin{array}{l}\text { Dipublikasi } \\
\text { Februari } 2019\end{array}$ & $\begin{array}{l}\text { Hasil penelitian menunjukkan bahwa kemampuan interaksi sosial peserta didik yang } \\
\text { rendah dapat ditingkatkan dengan menggunakan layanan Konseling Kelompok } \\
\text { dengan teknik sosiodrama. terbukti dari hasil analisis data kemampuan interaksi } \\
\text { sosial menggunakan uji } t \text {, dapat diketahui bahwa t hitung adalah }-10,180 \text { dengan nilai } \\
\text { probabilitas atau sig. ( } 2 \text {-tailed) sebesar } 0,000<0,05 \text {, karena nilai sig. (2-tailed) } \\
\text { sebesar } 0,000 \text { lebih kecil dari } 0,05 \text {. Jadi dapat ditarik kesimpulan bahwa konseling } \\
\text { kelompok dengan teknik Sosiodrama dapat meningkatkan kemampuan interaksi } \\
\text { sosial peserta didik kelas VII di MTs Hidayatul Insan Palangka Raya. }\end{array}$ \\
\hline
\end{tabular}

*E-mail:

diplan16II8I@gmail.com

Kata Kunci : Konseling Kelompok, sosiodrama, interaksi sosial.

\section{ABSTRACT}

The purpose of this study is to know the ability of low social interaction can be improved by using the services of Group Counseling with Sociodrama Technique in class VII students of MTs Hidayatul Insan Palangka Raya. The population in this study were 66 students. The number of research samples consisted of 7 students. This research includes quantitative research, the research method is the pre-experimental method One-group pre-test and post-test design .. Data collection techniques use the scale of social interaction. The data analysis technique used is the $t$ test (paired sample $T$ test) which is classified in parametric statistics. The results of the study show that the ability of low social interaction of students can be improved by using group counseling services with sociodrama techniques. it is evident from the results of data analysis of the ability of social interaction using the $t$ test, it can be seen that $t$ count is $-10,180$ with a probability value or sig. (2-tailed) of 0,000 $<0,05$, because of the sig value. (2-tailed) of 0,000 less than 0.05 . So it can be concluded that group counseling with Sociodrama techniques can improve the ability of social interaction of seventh grade students at MTs Hidayatul, Palangka Raya Staff.

Keywords: Group Counseling, sociodrama, social interaction. 


\section{PENDAHULUAN}

Manusia secara hakiki merupakan makhluk sosial, dimana ia dituntut untuk melakukan hubungan sosial antar sesama dalam hidupnya. Hubungan sosial itu merupakan salah satu hubungan yang harus dilaksanakan, mengandung pengertian bahwa dalam hubungan itu setiap individu menyadari tentang kehadirannya di samping kehadiran individu lain. hubungan antara individu satu dengan yang lain yang saling mempengaruhi dan membentuk interaksi sosial.Interaksi sosial merupakan hubungan dinamis yang menyangkut hubungan antara individu dengan individu, antara individu dengan kelompok, dan antara kelompok dengan kelompok.

Soekanto (Nursalim 2012: 84) bahwa interaksi sosial merupakan hubungan dinamis yang menyangkut hubungan antar orang perorangan, antar kelompok dengan kelompok, maupun antar orang perorangan dengan kelompok. Dari pengertian tersebut manusia di tuntut untuk mampu mengembangkan dan menyesuaikan diri terhadap masyarakat. Meningkatkan keterampilan interaksi sosial dengan teman dibutuhkan dukungan dari semua pihak baik itu guru, teman-teman, dan peserta didik itu sendiri. Oleh karena itu salah satu cara untuk meningkatkan kemampuan siswa dalam interaksi sosial di lingkungan sekolah adalah melalui konseling kelompok. Winkel (lubis, 20II:198) menjelaskan konseling kelompok merupakan pelaksanaan proses konseling yang dilakukan antara seorang profesional dan beberapa klien sekaligus dalam kelompok kecil. konseling kelompok memiliki beberapa teknik yang dapat diterapkan sesuai dengan kebutuhan dan pelaksanaannya. Salah satu teknik yang akan peneliti gunakan untuk mengatasi masalah tersebut adalah Teknik Sosiodrama.

\section{METODE PENELITIAN}

Penelitian ini menggunakan pendekatan Pre Ekperimental Design dengan menggunakan one group pre-test and post test design. Penelitian yang dilaksanakan pada satu kelompok saja tanpa kelompok pembanding. Dalam design ini observasi dilakukan sebanyak dua kali yaitu sebelum ekperimen dan sesudah eksperimen.
Obeservasi sebelum dilakukan eksperimen (OI) disebut pre-test dan observasi sesudah eksperimen (O2) disebut post-test. Arikunto (2013:85) pertama dilakukan pengukuran (pre-test) terhadap peserta didik kemudian diberi perlakuan konseling kelompok dengan teknik sosiodrama (treatment) setelah diberi perlakuan (post-test) untuk melihat ada tidaknya pengaruh konseling kelompok dengan teknik sosiodrama yang diterapkan dalam meningkatkan interaksi sosial pada peserta didik.

berikut :

Pola ini dapat digambarkan sebagai

Pre-test Treatment Post-test

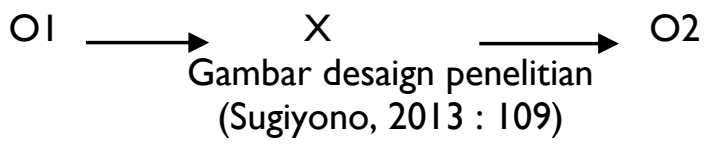

\section{HASIL DAN PEMBAHASAN \\ Pre-test dan post-test}

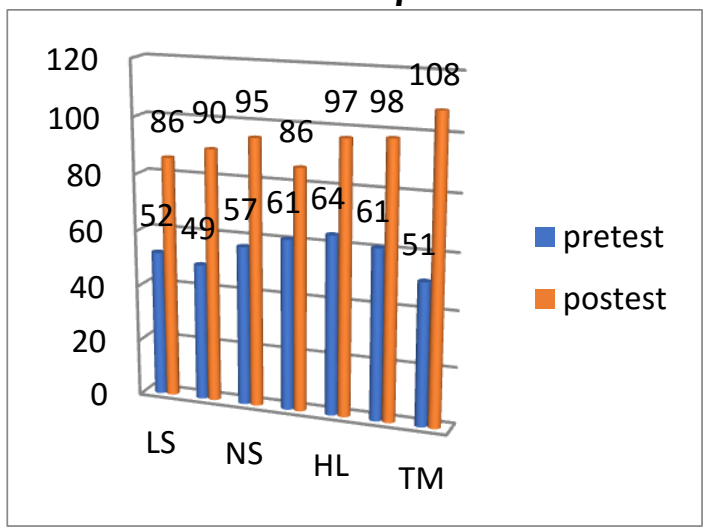

Berdasarkan hasil skor pre-test dan posttest tingkat kontrol diri peserta setelah mengikuti layanan konseling kelompok dengan teknik sosiodrama mengalami peningkatan yaitu skor post-test lebih tinggi daripada skor pre-test. Ketercapaian hasil tersebut karena layanan konseling kelompok dilaksanakan secara profesional sesuai dengan prosedur yang telah direncanakan.

\section{KESIMPULAN}

Berdasarkan hasil penelitian yang telah dilakukan mengenai pelaksanaan Konseling Kelompok dengan Menggunakan Teknik Sosiodrama untuk meningkatkan Interaksi Sosial peserta didik kelas VII di MTs. Hidayatul Insan Palangka Raya, dapat disimpulkan sebagai berikut : 
Jurnal Bimbingan dan Konseling

Ada perbedaan Interaksi sosial peserta didik kelas VII MTs Hidayatul Insan Palangka Raya sebelum pelaksanaan layanan konseling kelompok sosiodrama. hal ini dapat dilihat dari tingkat interaksi sosial peserta didik dengan pengkategorian sebagi berikut : diketahui bahwa penyesuaian diri dari 30 peserta didik di kelas VII MTs Hdayatul Insan Palangka Raya masuk dalalam kategori tinggi dengan frekuensi $45,45 \%$. Kemudian 19 peserta didik yang masuk dalam kategori sedang dengan frekuensi $28,78 \%$. Sedangkan 17 peserta didik masuk dalam kategori rendah dengan frekuensi $25,75 \%$. Ada peningkatan kemampuan interaksi sosial setelah dilakukan layanan konseling kelompok teknik sosiodrama.

Layanan konseling kelompok dengan teknik sosiodrama efektif dalam meningkatkan kemampuan interaksi sosial peserta didik kelas VII MTs Hidayatul Insan palangka Raya dengan diperoleh peningkatan skor dari 7 (tujuh) peserta didik yang menjadi subyek penelitian. Hal ini terbukti dari analisis hasil uji $\mathrm{t}$ (paired simple test) yang menunjukkan bahwa $t$ hitung adalah $-10,180$ dengan nilai probabilitas atau sig. (2-tailed) sebesar $0,000<0,05$, karena nilai sig. (2-tailed) sebesar 0,000 lebih kecil dari 0,05 .

\section{DAFTAR PUSTAKA}

Amti, Prayitno.2004. Dasar-Dasar Bimbingan dan Konseling. Jakarta: PT Rineka Cipta.

Aqib Zainal.2012. Ikhtisar Bimbingan dan Konseling di Sekolah. Bandung: Yrama Widya

Erford, Bradley T.2016.40 Teknik yang harus Diketahui setiap Konselor.Yogyakarta:PustakaPelajar.

Nurishan, Juntika dan Agustin, Mubiar .20II. Dinamika Perkembangan Anak dan Remaja. Bandung: Refika Aditama.

Rahkmat, Jalaluddin. 2005. Psikologi Komunikasi. Bandung: PT Remaja Rosdakarya.

Rusmana, Nandang.2009. Bimbingan dan Konseling Kelompok di Sekolah (Metode, Teknik dan Aplikasi). Bandung: Rizqi Press.

Eddy, Wibowo Mungin.2005. Konseling Kelompok Perkembangan. Semarang: Unnes Press.
Sarwono \& Meinarno. 2009. Psikologi Sosial. Jakarta: Salemba humanika.

Sukardi. K. Dewa. 2008. Pengantar Pelaksanaan Program Bimbingan dan

Konseling di Sekolah. Jakarta: PT. Rineka Cipta.

W. S. Winkel dan M.M. Sri Hastuti. 2004. Bimbingan Dan Konseling Di Institusi Pendidikan. Yogyakarta: Media Abadi.

Sugiyono. 2010. Metode Penelitian Pendidikan Pendekatan Kuantitatif, Kualitatif,dan R\&D. Bandung: Alfabeta

Syamsu Yusuf. 2004. Psikologi Perkembangan Anak dan Remaja. Bandung: PT Remaja Rosdakarya.

Tohirin. 2007. Bimbingan dan Konseling Di Sekolah. Jakarta: PT Grafindo Persada.

Walgito, B. 20I0. Psikologi Sosial Suatu Pengantar. Yogyakarta: Andi Yogyakarta 